* Acadêmica do $5^{\circ}$ ano do Curso de Direito da Universidade Estadual de Londrina.

** Acadêmico do $5^{\circ}$ ano do Curso de Direito da Universidade Estadual de Londrina. E-mail: tadeu_migoto@hotmail.com

\section{A Interpretação da Imunidade do Art. 150, VI, D, da Constituição Federal em Conformidade com o Estado Democrático de Direito}

\author{
THE INTERPRETATION OF THE IMMUNITY GRANTED \\ BY THE ART. 150, VI, D, FROM THE FEDERAL \\ Constitution AcCording to the \\ Democractic State of Law
}

\author{
Isabela Moraes Almeida Lopes * \\ Tadeu José Migoto Filho **
}

Resumo: O presente trabalho desenvolve o tema da imunidade tributária dos livros, jornais, periódicos e o papel destinado à sua impressão, com enfoque na sua forma garantidora de direitos. Tem por objetivo o estudo acerca do Estado Democrático de Direito, dos direitos fundamentais à liberdade de expressão, bem como à cultura. Apresenta o foco atual dado a tal imunidade e sua interpretação em conformidade com o Estado Democrático de Direito, abordando sua importância, relevância e complexidade.

Palavras-chave: Estado Democrático de Direito; imunidade tributária; liberdade de expressão; acesso à cultura.

Abstract: The present paper addresses the matter of fiscal immunity granted to books, journals, newspapers, magazines and the paper destined to their print, interpreting the immunity as a way of guaranteeing fundamental rights. Its scope concerns the study about the Democratic State of Law, as well as the constitutional rights of free speech and universal access to culture. It also exposes the actual focus given to such immunity and its interpretation according to the Democratic State of Law, addressing its importance, relevance and complexity.

Keywords: Democratic State of Law; fiscal immunity; free speech; cultural access. 


\section{INTRODUÇÃO}

A imunidade tributária gera diversas discussões, alguns autores destacam o caráter político das imunidades tributárias, outros afirmam ser a imunidade a exclusão do próprio poder de tributar, ou hipótese de não-incidência constitucionalmente qualificada, ou ainda, supressão da competência impositiva.

$\mathrm{O}$ art. 150, VI, alínea "d" da Constituição Federal garante imunidade tributária aos livros, jornais, periódicos e o papel destinado à sua impressão, gerando diversos questionamentos quanto à extensão deste benefício. Além disso, a imunidade é um limite ao poder de tributar do Estado, um obstáculo decorrente de uma regra constitucional à incidência da norma jurídica tributária, gerando debates.

Os princípios que norteiam tal imunidade tais como a preservação da liberdade de expressão intelectual, científica, artística e de manifestação do pensamento, dentre outros, não são os únicos fundamentos da imunidade prevista no artigo 150, VI, "d" da Carta Magna, posto também se prestar ela a garantir a irradiação da cultura e da educação, mediante o barateamento dos livros, jornais e periódicos, facilitando, destarte, o acesso aos bens necessários para a formação intelectual do homem.

O presente trabalho pretende, por fim, realizar uma análise, valendo-se do método de revisão bibliográfica de tal espécie de imunidade à luz do Estado Democrático de Direito a fim de desvendar seu real alcance dentro do ordenamento jurídico brasileiro.

\section{ESTADO DEMOCRÁTICO DE DIREITO}

A afirmação contida no enunciado do art. $1^{\circ}$ da Carta Magna de que a República Federativa do Brasil constitui-se em um Estado Democrático de Direito implica em dizer que o Estado brasileiro é mais do que um Estado de Direito, isto é, não esgota suas possibilidades apenas em um governo regido por leis, ao invés de homens; submisso, portanto, ao império da lei. Ora, tal conceito vai além para conceder uma legitimação democrática ao exercício do poder (CANOTILHO, 2003, p.98).

A opção constitucional por um Estado Democrático de Direito se justifica na medida em que ao longo da história se vislumbrou a falência do Estado de Direito como forma de estruturação da vida política. Isso porque, conforme ensina José Afonso da Silva (2005, p.113) houve tantas concepções de Estado 
de Direito quanto às diferentes concepções possíveis que se tem de Direito, muitas das quais não se assentam no princípio democrático de legitimação do poder. Assim, observa-se que a dita falência do modelo de Estado em tela decorreu de seu uso como respaldo para a instauração de regimes ditatoriais (SILVA, 2005, p.113-115), incompatíveis com a proteção da dignidade da pessoa humana.

Com efeito, a concepção de Estado Democrático de Direito não se trata de mera justaposição das noções de Estado Democrático e Estado de Direito, senão na construção de um conceito novo, "que leva em conta os conceitos dos elementos componentes, mas os supera na medida em que incorpora um componente revolucionário de transformação do status quo" (SILVA, 2005, p.119). Nesse diapasão, Coelho (BRANCO; COELHO e MENDES, 2009, p.171) entende como Estado Democrático de Direito,

“[...] a organização política em que o poder emana do povo, que o exerce diretamente ou por meio de representantes, escolhidos em eleições livres e periódicas, mediante sufrágio universal e voto direito e secreto, para o exercício de mandatos periódicos, como proclama, entre outras, a Constituição brasileira. Mais ainda, já agora no plano das relações concretas entre o Poder e o indivíduo, considera-se democrático aquele Estado de Direito que se empenha em assegurar aos seus cidadãos o exercício efetivo não somente dos direitos civis e políticos, mas também e sobretudo dos direitos econômicos, sociais e culturais, sem os quais de nada valeira a solene proclamação daqueles direitos"

Cabe ressaltar que tal concepção prima por explicar o modelo de Estado trazido à baila pelo âmbito da legitimação do exercício do poder, o qual, dentro do contexto democrático deverá sempre ser exercido em conformidade com a fórmula de Lincoln (CANOTILHO, 2003, p.287), ou seja, em nome do povo, para o povo e pelo povo; e também, pelo aspecto da relação de Poder entre a Administração Pública e os cidadãos, a qual deve expressar uma interação de governança com respeito aos direitos fundamentais de todas as gerações.

José Afonso da Silva (2005, p.119-120) compreende que a democracia que qualifica o Estado de Direito dentro da Constituição brasileira, há de ser

“[...] um processo de convivência social em uma sociedade livre, justa e solidária $\left(\operatorname{art.} 3^{\circ}, \mathrm{I}\right)$, em que o poder emana do povo, e deve ser exercido em proveito do povo, diretamente ou por representantes eleitos (art. $1^{\circ}$, parágrafo 
único); participativa, porque envolve a participação crescente do povo no processo decisório e na formação dos atos de governo ${ }^{1}$; pluralista, porque respeita a pluralidade de ideias, culturas e etnias ${ }^{2}$ e pressupõe, assim, o diálogo entre e pensamentos divergentes e a possibilidade de convivência de formas de organização e interesses diferentes da sociedade; há de ser um processo de liberação da pessoa humana das formas de opressão que não depende apenas do reconhecimento formal de certos direitos individuais, políticos e sociais, mas especialmente da vigência de condições econômicas suscetíveis de favorecer o seu pleno exercício."

Assim, observa-se que o princípio democrático, corolário natural do modelo de Estado trazido à baila (o qual emana precipuamente do art. $1^{\circ}$, caput $\mathrm{e}$ parágrafo único da Constituição pátria), irradia-se para todo o ordenamento jurídico tanto como norma de comportamento como de estrutura. Caracterizase, verdadeiramente, segundo Canotilho (2003, p.289-290) como princípio informador do Estado e da sociedade, na medida em que aponta para um processo dinâmico de "democratização extensivo a diferentes aspectos da vida económica, social e cultural"; assim como princípio organizador da titularidade e exercício do poder político.

Contudo, o princípio democrático, para germinar, necessita, como bem lembra o notável constitucionalista português (CANOTILHO, 2003, p.290-291), do terreno fértil dos direitos fundamentais. Isso porque tais direitos revelam-se intimamente conjugados com o princípio democrático, já que os direitos subjetivos de participação e associação constituem-se como fundamentos funcionais da democracia; enquanto que os direitos de liberdade figuram como um abrigo contra o exercício do poder autoritário e, como "legitimadores de um domínio democrático, asseguram o exercício da democracia mediante a exigência de garantias de organização e de processos com transparência democrática"; por fim, os direitos econômicos, sociais e culturais representam pressupostos impositivos para o "preenchimento intrínseco" dos supracitados direitos.

Em que pese o Estado Democrático de Direito não seja apenas uma soma dos conceitos de Estado Democrático e Estado de Direito, conforme anteriormente dito, isso não implica que ele não seja um governo de leis, regido pelo império do direito. Pelo contrário, por ser o Estado em tela também um Estado de Direito, pode-se afirmar que está em sua essência a submissão à legalidade. Contudo, não se trata de uma obediência cega a toda e qualquer lei, mas a somente àquela em seu sentido democrático, isto é, "que realize o princípio da igualdade e da justiça não pela sua generalidade, 
mas pela busca da igualização das condições dos socialmente desiguais" (SILVA, 2005 , p.121).

Assim, verifica-se que a lei, no Estado Democrático de Direito ganha novos contornos, para além daquela esboçada pelo modelo clássico de Estado de Direito. A lei que deve reger o governo do Estado Democrático de Direito é aquela, portanto, que transcende a etérea esfera puramente normativa e influi concretamente na vida social, provocando transformações verdadeiramente democráticas na sociedade a que se destina (SILVA, 2005, p.121-122).

\section{DIREITOS FUNDAMENTAIS}

Os direitos fundamentais do homem, na atual Constituição abrangem os direitos individuais, políticos e sociais. Tais direitos foram apenas recentemente transformados em enunciados explícitos nas declarações de direitos, estando longe de se esgotarem todas suas possibilidades, já que cada passo na etapa da evolução da Humanidade importa na conquista de novos direitos.

Com a evolução das declarações de direitos observou-se a criação de uma forma de assegurar sua efetividade através de um conjunto de meios e recursos jurídicos que passaram a se chamar garantias constitucionais dos direitos fundamentais. Biscaretti di Ruffia (1970, p.695 e 696) apresentou este fenômeno da seguinte forma:

"No curso do século XIX, a enunciação dos direitos e deveres dos indivíduos sofreu uma dupla transformação: passou para o próprio texto das Constituições, imprimindo às suas fórmulas, até então abstratas, o caráter concreto de normas jurídicas positivas (ainda que de conteúdo geral e de princípio), válidas para os indivíduos dos respectivos Estados (dita subjetivação), e, não raro, integrou-se também de outras normas destinadas a atuar uma completa e pormenorizada regulamentação jurídica de seus pontos mais delicados, de modo a não requerer ulteriormente, a tal propósito, a intervenção do legislador ordinário (ou seja, sua positivação)".

Assim, as declarações de direitos assumiram, inicialmente, a forma de proclamações solenes, depois passaram a constituir o preâmbulo das constituições, sendo, atualmente, parte das constituições, com caráter de normas jurídicas positivas constitucionais, na medida em que se inserem no texto de uma constituição ou mesmo constem de simples declaração solenemente 
estabelecida pelo poder constituinte. São direitos que nascem e se fundamentam, portanto, no princípio da soberania popular.

Para José Afonso da Silva, tanto a eficácia quanto a aplicabilidade das normas que contêm os direitos fundamentais dependem de seu enunciado (SILVA, 2008a, p.180). A Constituição é expressa sobre o assunto, uma vez que estatui que as normas definidoras dos direitos e garantias fundamentais tem aplicação imediata. Porém, nem todas as questões se resolvem à partir deste enunciado, tendo em vista que a própria Constituição faz depender de legislação ulterior a aplicabilidade de algumas normas definidoras dos direitos sociais, que compõem os direitos fundamentais. Assim, por regra, as normas que consubstanciam os direitos fundamentais democráticos e individuais são de eficácia contida e aplicabilidade imediata, enquanto as que definem os direitos econômicos e sociais podem ser de eficácia limitada, de princípios programáticos e de aplicabilidade indireta, mas são tão jurídicas quanto as outras e exercem relevante função. (SILVA, 2008b, p.91).

Para o mesmo autor, os direitos fundamentais apresentam os seguintes caracteres: a) Historicidade, pois nasceram com a revolução burguesa e evoluem, ampliam-se, com o correr dos tempos; b) Inalienabilidade, uma vez que são intransferíveis, inegociáveis, por não serem de conteúdo econômico-patrimonial; c) Imprescritibilidade, considerando que tais direitos nunca deixam de ser exigíveis, não se verificam requisitos que importem em sua prescrição. d) Irrenunciabilidade, tendo em vista que, ainda que não sejam utilizados, tais direitos não podem ser renunciados. (SILVA, 2008a, p.182).

Quanto à classificação destes direitos, é possível encontrar em diferentes autores, distintas classificações, porém, a que decorre do nosso Direito Constitucional é aquela que os agrupa com base no critério de seu conteúdo, que, ao mesmo tempo, se refere à natureza do bem protegido e do objeto de tutela. Assim, temos: a) direitos individuais, se encontram no art. $5^{\circ}$, sendo aqueles que reconhecem autonomia aos particulares; b) direitos à nacionalidade, têm por conteúdo e objeto a definição de nacionalidade e suas faculdades (art. 12); c) direitos políticos, previstos nos arts. 14 a 17; d) direitos sociais, que constituem os direitos assegurados ao homem em suas relações sociais e culturais (arts. $6^{\circ}$ e 193 e ss); e) direitos coletivos, também no art. 5º e f) direitos solidários, também chamados direitos de terceira geração, compreendidos o direito à paz, comunicação, desenvolvimento, meio ambiente e patrimônio comum da humanidade (arts. $3^{\circ}$ e 225). Vale ressaltar que a Constituição, porém, não inclui os direitos fundados nas relações econômicas entre os direitos fundamentais sociais. 


\section{DIREITO À LIBERDADE DE EXPRESSÃO}

A doutrina brasileira apresenta-se bastante imprecisa acerca do real significado e abrangência do termo "liberdade de expressão". Pode-se afirmar, inclusive, que parte desta imprecisão é atribuída ao próprio legislador que, em momentos distintos, utilizou-se do termo para a mesma liberdade de expressão, em diversos incisos do art. $5^{\circ}$ da Constituição de 1988.

Ela se caracteriza como exteriorização do pensamento no seu sentido mais abrangente. É que, no seu sentido interno, como pura consciência, como pura crença, mera opinião, a liberdade de pensamento é plenamente reconhecida, mas não cria problema maior. Pimenta Bueno (apud. SILVA, 2008a, p.241) já dizia que:

"a liberdade de pensamento em si mesmo, enquanto o homem não manifesta exteriormente, enquanto o não comunica, está fora de todo poder social, até então é de domínio somente do próprio homem, de sua inteligência e de Deus. [...] O homem porém não vive concentrado só em seu espírito, não vive isolado, por isso mesmo que por sua natureza é um ente social. Ele tem a viva tendência e necessidade de expressar e trocar suas idéias e opiniões com os outros homens, de cultivar mútuas relações, seria mesmo impossível vedar, porque fora para isso necessário dissolver e proibir a sociedade".

Vidal Serrano Nunes Junior (1997 p.28-29), afirma que o direito de expressão consiste na:

“exteriorização de sensações, tais como a música, a pintura, a manifestação teatral, a fotografia etc. [...] Ou seja, por intermédio dela (expressão) o indivíduo exterioriza suas sensações, seus sentimentos ou sua criatividade, independentemente da formulação das convicções, juízos de valor ou conceitos".

Portanto, a liberdade de expressão há de se prestar à realização pessoal, formação individual e à livre opção de cada um, não podendo ser instrumento contrário à realização pessoal, pois seria contraditório que um fato pudesse, ao mesmo tempo, apoiar-se na liberdade de expressão e violá-la, enquanto categoria constitucional, em determinado caso concreto.

Esta liberdade é composta tanto de uma dimensão substantiva como de uma instrumental, a substantiva compreende a atividade de pensar, formar a 
própria opinião e exteriorizá-la. A instrumental traduz a possibilidade de utilizar os mais diversos meios adequados à divulgação do pensamento. Além disso, há as dimensões individual e coletiva da liberdade de expressão, a primeira garante ao indivíduo a possibilidade de se formar, de ser sem ter de se adequar a um modelo previamente determinado, já a coletiva garante a possibilidade de abarcar também terceiros.

Porém, conforme Nuno e Souza (1984, p.156) enfatiza: "Toda a liberdade tem limites lógicos, isto é, consubstanciais ao próprio conceito de liberdade". Seguindo este entendimento, tem-se como requisito para o exercício da liberdade de expressão que esta não prejudique ninguém, em nenhum de seus direitos.

Conforme se pode extrair da leitura da melhor doutrina, não há nenhuma precedência preestabelecida entre os diversos princípios (que ensejam direitos), o que, em parte, equivale a afirmar que não se admite nenhum direito como absoluto. Para o autor (SOUZA, 1984, p.268) apresentam-se como limites imediatos à liberdade de expressão:

"os direitos à imagem, à identidade pessoal, ao bom nome e reputação e à reserva da intimidade da vida privada e familiar (...)". Assim, veda-se "a utilização abusiva (mas sem atingir o grau mais grave da dignidade humana), ou contrária à dignidade humana, de informações relativas às pessoas e famílias; portanto, o uso abusivo de informações sobre as pessoas e famílias, mesmo que não contrarie diretamente a dignidade humana, é ilícito".

"A existências dessas limitações ao direito à liberdade de expressão se explicam tanto (i) pela necessidade de harmonia entre os direitos individuais como (ii) por questão de coerência, visto que seria, no mínimo, contraditório se a liberdade de expressão, que é um direito engendrado pelo homem para assegurar e possibilitar sua autodeterminação individual, estivesse em contradição com essa mesma finalidade, atentando contra o desenvolvimento da personalidade individual e desrespeitando direitos essências à própria personalidade.”(RAMOS TAVARES, André, 2007, p.558).

Se a liberdade de expressão encontra-se tutelada para, dentre outras finalidades, assegurar a formação da personalidade individual, seria insuportável que seu exercício trouxesse justamente o desrespeito a direitos da personalidade e, ademais, provocasse com isso aquela formação por meio das divulgações viciadas, gerando uma mensagem implícita de que os direitos podem ser violados.

Importante ressaltar que a liberdade de expressão não existe para si mesma. Ainda que se defenda sua condição de direito natural, tal somente 
existiria no mundo fenomênico em sua necessária relação com o homem (TAVARES, 2007, p.554). Não haveria que falar em liberdade de expressão se este, único ser racional e capaz de se expressar, não subsistisse, Daí ser um meio e não um fim em si mesma.

\section{DIREITO À CULTURA}

A Constituição de 1988 deu relevante importância à cultura, utilizando este termo em sentido abrangente da formação educacional do povo, expressão criadora da pessoa e das projeções do espírito humano materializadas em suportes expressivos, portadores de referências à identidade, à ação, à memória dos diferentes grupos formadores da sociedade brasileira, que se exprimem por vários de seus artigos ( $5^{\circ}$, IX, 23, III a V, 24, VII a IX, e 205 a 217), formando aquilo que se denomina ordem constitucional da cultura, constituída pelo conjunto de normas que contêm referências culturais e disposições consubstanciadoras dos direitos sociais relativos à educação e à cultura. José Afonso da Silva (2001, p.39), em um breve retrospecto histórico identifica a origem da preocupação com o tema:

"A cultura passou a integrar os textos constitucionais a partir do momento em que as Constituições abriram um título especial para a ordem econômica, social, educação e cultura - o que se deu primeiro com a Constituição Mexicana de 1918, e esta com maior influência sobre as Cartas Políticas produzidas entre as duas Grandes Guerras Mundiais. Foi daí que veio a norma do art. 48 da Constituição de 1934, que dispôs sobre a proteção das ciências, das artes, das letras e da cultura em geral”.

Apesar de não terem sido arrolados no art. $6^{\circ}$ como espécies de direito social, os direitos culturais o são, por ter sido o direito à educação ali arrolada. Além disso, estão esses direitos expressos no art. 215, consoante o qual o Estado garantirá a todos o pleno exercício dos direitos culturais e acesso às fontes da cultura nacional, e apoiará e incentivará a valorização e a difusão das manifestações culturais. Deste artigo também se extrai o princípio da universalidade atribuído a tal direito, ou seja, é garantido a todos.

Os direitos culturais reconhecidos na Constituição são: a) direito de criação cultural, compreendidas as criações científicas, artísticas e tecnológicas; b) direito de acesso às fontes da cultura nacional; c) direito de difusão da cultura; d) liberdade de formas de expressão cultural; e) liberdade de manifestações 
culturais; f) direito-dever estatal de formação do patrimônio cultural brasileiro e de proteção dos bens de cultura, que, assim, ficam sujeitos a um regime jurídico especial, como forma de propriedade de interesse público.

Em 10 de agosto de 2005, promulgou-se a Emenda Constitucional n. 48 que encartou, no artigo 215 da Constituição Federal, o $\S 3^{\circ}$. Neste dispôs-se que a lei estabelecerá o Plano Nacional de Cultura, de duração plurianual, visando o desenvolvimento cultural do País, uma lacuna, de fato, irrefutável, e à integração das ações do poder público que conduzam à (i) defesa e valorização do patrimônio cultural brasileiro; (ii) produção, promoção e difusão de bens culturais; (iii) formação de pessoal qualificado para a gestão da cultura em suas múltiplas dimensões; (iv) democratização do acesso aos bens de cultura; e (v) valorização da diversidade étnica e regional.

\section{IMUNIDADE}

As competências para instituir tributos são delineadas pelas Constituição Federal em seu bojo normativo, tanto por meio de normas positivas quanto negativas, entendendo-se, as últimas como formas de restrição ao poder de tributação do Estado. Ora, é dentro dessa categoria de regras jurídicas que as imunidades estão compreendidas. Tratam-se, portanto, de normas que limitam o poder de tributação ao estabelecerem incompetências aos entes da federação para "onerar, com exações, certas pessoas, seja em função de sua natureza jurídica, seja porque coligadas a determinados fatos, bens ou situações" (CARRAZZA, 2009, p. 725). Nessa esteira, Paulo de Barros Carvalho (2010, p.234) conceitua imunidade como:

“[...] a classe finita e imediatamente determinável de normas jurídicas, contidas no texto da Constituição Federal, e que estabelecem, de modo expresso, a incompetência das pessoas políticas de direito constitucional interno para expedir regras instituidoras de tributos que alcancem situações específicas e suficientemente caracterizadas".

As imunidades tem como fonte necessária a Carta Magna e emanam, principalmente, do comando do art. 150, VI, embora não se esgotem nesse dispositivo, podendo ser encontradas normas de imunidades por toda a Constituição, como por exemplo, no art. $153, \S 4^{\circ}$, II. De uma breve análise do art. 150, VI, depreende-se que foi estabelecida uma vedação constitucional às pessoas de direito público interno em instituir impostos sobre: patrimônio, rendas 
e serviços uns dos outros; templos de qualquer culto; patrimônio, renda ou serviços dos partidos políticos, inclusive suas fundações, das entidades sindicais dos trabalhadores, das instituições de educação e de assistência social, sem fins lucrativos; e livros, jornais, periódicos e o papel destinado a sua impressão.

É possível, portanto, inferir que o constituinte, ao criar normas prevendo a imunidade de certas pessoas e/ou coisas, assim o fez com a precípua finalidade de "preservar da tributação valores de particular significado político, social ou econômico" para o Estado brasileiro (CARRAZA, 2009, p.734).

Com efeito, ao estabelecerem restrições ao poder das pessoas políticas de direito público interno em criar normas jurídicas que instituam tributos em face de certos valores constitucionalmente protegidos, as imunidades são consideradas (CARVALHO, 2010, p.235) como normas de estrutura, vez que atuam diretamente sobre a atividade legiferante do Estado, impondo-lhe determinadas restrições.

Assim, por se tratarem as imunidades de normas de estrutura que balizam os limites da competência tributária das entidades da federação, tutelando, desta forma, valores essenciais ao Estado pátrio, verifica-se que tal instituto tributário é amplo e indivisível, não sendo admissível, nem por parte do legislador, quanto menos por parte do aplicador (seja o juiz ou o próprio agente fiscal) reduzir as imunidades (CARRAZA, 2009, p.729).

Carraza (2009, p.730) vai ainda além e consagra as imunidades como garantias fundamentais do contribuinte, dotadas de eficácia plena e aplicabilidade imediata (art. $5^{\circ}, \S 1^{\circ}$ da $\mathrm{CF}$ ), gozando, portanto, do status de cláusula pétrea, não podendo ser restringidas nem mesmo por meio de emenda constitucional.

\section{A INTERPRETAÇÃO DA IMUNIDADE DO ART. 150, VI, d, DA CONSTITUIÇÃO FEDERAL EM CONFORMIDADE COM O ESTADO DEMOCRÁTICO DE DIREITO}

O art. 150, VI, d, da Constituição Federal proibiu as pessoas políticas de direito constitucional de instituir impostos sobre livros, jornais, periódicos e o papel destinado a sua impressão, consagrando, dessa forma, uma imunidade a tais bens.

Com efeito, tal imunidade tributária encontra justificativa na necessidade exigida pelo Estado Democrático de Direito de proteção ao direito fundamental à liberdade de expressão, essencial para a difusão da cultura e materialização do direito de acesso à educação de qualidade. Conforme ensina Machado (1998, 
p.83) a imunidade em tela tem o precípuo fim de proteger os supracitados bens "contra todo e qualquer imposto, porque o imposto pode ser instrumento de inviabilização" dos referidos direitos. Nessa esteira, o eminente jurista pensa na imunidade como mecanismo de salvaguarda contra futuros impostos a serem criados "com o propósito de onerar excessivamente esses bens e, assim, prejudicar a divulgação de idéias, a disseminação da cultura".

Ora, tamanha é a importância da tutela à liberdade de expressão no Estado Democrático de Direito que como magistralmente leciona Pontes de Miranda (1974, p.155-156, apud CARRAZZA, 2009, p.792-793).

"Se falta liberdade de pensamento, todas as outras liberdades humanas estão sacrificadas, desde os fundamentos. Foram os alicerces mesmos que cederam. Todo o edifício tem de ruir. Dá-se a tentativa de fazer o homem parar: voltar ao infracultural, ou ao infra-humano. Todo Prometeu, que descubra o fogo, será punido. Como toda ordem vigente foi feita no passado, apertam-se as consciências para apequená-las ao tamanho, que era o delas, ao tempo em que a ordem vigente se criou, ou antes dela, por 'força da queda' de toda regressão".

Outrossim, Carrazza (2009, p.793) bem ensina que "a própria democracia de um País é diretamente proporcional ao grau de livre manifestação do pensamento que nele existe". Isso porque, conforme assinalado anteriormente, os direitos de liberdade (em especial a liberdade de expressão) concretizam-se como formas de abrigo e controle contra o poder antidemocrático.

Verifica-se, portanto que sem tal liberdade, inviável seria o exercício de qualquer espécie de governo democrático, motivo pelo qual a Carta Política instituiu a imunidade para os livros, jornais e periódicos: para figurar como garantia material de concretização da liberdade de expressão e, assim, possibilitar a realização prática do Estado Democrático de Direito.

Levando em consideração que a imunidade do art. 150, VI, d, da CF repousa a sua razão de ser sobre a necessidade de garantia da livre divulgação de idéias e pensamentos em uma sociedade democrática, resta saber qual é a verdadeira acepção de livro adotada pelo legislador constituinte, a fím de identificar quais bens estariam sob o manto da imunidade tributária.

Dessa forma, como a finalidade maior da imunidade trazida à baila é assegurar a todos o direito fundamental à liberdade de expressão, constata-se que a interpretação mais adequada à concretização desse fim é a de que a imunidade deve abranger todo e qualquer veículo de idéias equiparado ao livro 
(tais como CD-rom, DVD, disquete, etc.), libertando-se de uma interpretação exclusivamente literal, que a restringe somente ao livro impresso.

Como pontuado anteriormente, o Estado Democrático de Direito, diferencia-se do Estado de Direito, justamente por não se submeter cegamente ao império de qualquer lei, mas sim e somente sim daquela lei democraticamente elaborada que provoque reais transformações democráticas no meio social a que se destina. Desta forma, não se pode ignorar que na sociedade contemporânea as mídias eletrônicas e analógicas diversas do papel são utilizadas tanto quanto, ou quiçá até mais que este, como meio de disseminação de idéias e pensamentos. Como bem lembra Carrazza (2009, p.795) a evolução tecnológica revela uma tendência de substituição do papel pelos novos meios de difusão de pensamento; evolução esta que quando deixar de ser mera previsão para concretizar-se como realidade tornará letra morta a norma constitucional da imunidade em tela (se for seguida a sua interpretação restritiva), negando, desse modo, a sua força normativa.

Com efeito, observa-se que reduzir a imunidade em debate a somente o livro impresso implica em ignorar o propósito e o próprio conceito de norma jurídica dentro do contexto do Estado Democrático de Direito, uma vez que cega sua interpretação, impedindo-a de se adequar a sociedade em que está inserida e às futuras transformações tecnológicas que estão por vir.

Sobre o assunto, Machado (2004, p.273) adverte que a melhor interpretação da Constituição é aquela que lhe concede a maior eficácia possível. Destarte, como toda imunidade tem por fim a proteção de valores fundamentais para a sociedade brasileira e como a imunidade em questão visa, em sua essência assegurar a livre de divulgação de idéias e disseminação da cultura, sendo inegável o papel das modernas mídias na consecução desse objetivo, ensina o citado autor que qualquer entendimento contrário a uma intepretação extensiva ao conceito de livro "leva a norma imu-nizante a uma forma de esclerose precoce, inteiramente incompatível com a doutrina do moderno constitucionalismo, especialmente no que concer-ne à interpretação especificamente constitucional".

Não se pode olvidar, igualmente, que as normas constitucionais devem ser interpretadas levando também em consideração os princípios da unidade constitucional e da correção funcional. Pelo primeiro entende-se que a Carta Magna é um todo unitário e assim deve ser interpretada, incorrendo em erro o hermeneuta que a interpretar a norma constitucional de modo fracionário, alienada do conjunto em que está inserida (BRANCO; COELHO; e MENDES, 
2009, p.136). Já o segundo, verdadeiro corolário do primeiro, implica em dizer que na exegese da Constituição "não podem os seus aplicadores chegar a resultados que perturbem o esquema organizatório-funcional nela estabelecido, como é o caso da separação dos poderes, cuja observância é consubstancial à própria idéia de Estado de Direito" (BRANCO; COELHO; e MENDES, 2009, p.138).

Deste modo, negar o status de livro às modernas mídias equivale a promover a exegese do art. 150, VI, d, da Carta Política perdendo de vista os seus mais fundamentais princípios de interpretação, já que que não leva em consideração o contexto jurídico no qual está inserida. Isso porque o aperfeiçoamento do Estado Democrático de Direito depende de uma ampla materialização da liberdade de expressão (tanto em seu âmbito substancial como instrumental), o qual é obstaculizado pela interpretação literal e reducionista do termo livro. Tal leitura, portanto, vai de encontro com o próprio modelo organizatório-funcional de Estado enunciado no art. $1^{\circ}$ da Constituição da República, tipificando verdadeira involução no modo com que se interpreta a Lei Fundamental.

Nesse diapasão, tributar e-book contido em um CD-rom e não tributar o mesmo livro, em sua versão impressa, consiste, como bem atenta Carrazza (2009, p.796-797), em uma violência outro princípio constitucional, o da isonomia (ignorando mais uma vez o caráter unitário da Constituição), vez que estaria o Fisco tratando duas situações idênticas de forma distinta, promovendo a injustiça e desestimulando o avanço tecnológico do país.

Ademais, admitir a tributação das modernas mídias significa, como lembra Machado (1998, p.85) abrir uma porta para o autoritarismo, visto que concede ao Estado a possibilidade de se valer da fiscalidade como meio de censura a certas formas de expressar o pensamento. Não se coaduna, portanto, com o Estado Democrático de Direito o sacrifício do valor liberdade em prol da sede arrecadadora do Fisco. Logo, em função de seu papel fundamental no sistema jurídico, leciona Carrazza (2009, p.732733), que as imunidades não podem ser ignoradas, nem sob o louvável pretexto de evitar a evasão tributária, constituindo verdadeiro direito subjetivo em favor do contribuinte de exigir do Poder Público que se abstenha de cobrar-lhes certos tributos.

Nesse sentido, contra a interpretação de que a extensão da imunidade do livro representaria inestimável perda aos cofres públicos, Machado (1998, p.84-85) dispõe que 
"A preocupação fiscalista não justifica, de nenhum modo, que se abra mão dos instrumentos de proteção da liberdade de expressão, contra os ímpetos, cada vez maiores, do poder tributário, até porque não faltarão ao Estado meios de suprir suas necessidades financeiras, e certamente poderá fazê-lo, sem o sacrifício da liberdade de comunicação e expressão".

De outra sorte, a extensão da imunidade às modernas formas de difusão de idéias, implica em um incentivo ao uso dessas tecnologias para transmissão da cultura; tecnologias essas que se revelam mais ecologicamente saudáveis que o papel (CARRAZZA, 2009, p.795), o qual, além de ocupar maior espaço físico (vez que as mídias digitais têm dimensões reduzidas e superior capacidade de armazenamento de dados), resulta de um nocivo processo de destruição da flora.

Destarte, constata-se que uma interpretação extensiva do termo livro no art. 150, VI, d, da Constituição conduz a um aperfeiçoamento do Estado Democrático de Direito, nos termos do art. $1^{\circ}$ caput e par. único, ao desenvolvimento tecnológico e científico, consoante art. 218, e à promoção de um meio ambiente ecologicamente equilibrado, conforme art. 225, caput, todos da Lei Maior.

No que tange aos insumos utilizados para a produção do livro, a doutrina clássica tende a defender que esta somente se restringe ao papel, principalmente por razões históricas: a imunidade do papel remonta à época do Estado Novo, em que o Governo censurava os jornais e periódicos da oposição, impedindo que recebessem papel de imprensa.

Depreende-se, portanto, dessa interpretação história, que o que se pretende proteger não é o papel, mas sim a liberdade de expressão contra a censura materializada, no caso, pela tributação excessiva, por se tratar de medida autoritária, incompatível com o espírito do Estado Democrático. Assim, não deve merecer proteção contra a censura somente o papel (matéria-prima por excelência do livro impresso), senão todas as espécies de insumos destinados à confecção do livro (tal como a tinta) em sua ampla acepção (devendo, também ser imunes as matérias-primas do CD-rom, por exemplo), sob pena de se incidir em uma violação ao princípio da isonomia.

\section{CONCLUSÃO}

A imunidade consiste em um mecanismo jurídico de preservação de valores constitucionalmente essenciais do poder fiscal do Estado. A imunidade do art. 
150, VI, d, da Constituição tem por escopo a proteção da liberdade de expressão e o acesso à cultura, os quais representam verdadeiras pedras-de-toque do Estado Democrático de Direito, vez que sem estes tornar-se-ia inviável a legitimação democrática de qualquer forma de exercício do poder.

O Estado Democrático de Direito revela-se intimamente esposado com a tutela dos direitos fundamentais, em especial com a liberdade de difusão do pensamento, visto que sem a plena realização desta, tanto em seu plano substancial, quanto instrumental, mostra-se impossível frear os impulsos autoritários de seus líderes e organizar formas democráticas de representação, neutralizando qualquer tentativa de libertação do homem contra os modelos opressores de governo.

De outra sorte, a restrição à livre expressão de idéias põe em xeque ao acesso à cultura, verdadeiro fundamento para a concretização do direito à educação, o qual é pressuposto para a salvaguarda da dignidade da pessoa humana e pré-requisito para garantir o desenvolvimento nacional, objetivo da República, encartado no art. $3^{\circ}$, II da Carta Política.

Observa-se, por conseguinte, que uma interpretação constitucional que prime pela máxima efetividade da Constituição deve, antes de tudo, olhar para o texto do direito positivo que contém a imunidade do livro e extrair-lhe uma norma jurídica que sirva como forma de abrigo para esses valores tão caros ao Estado Democrático de Direito.

Outrossim, importa lembrar que a melhor didática constitucional ensina que a Carta Magna deve ser interpretada com um todo unitário, não podendo a sua exegese contrariar sua própria estrutura organizacional.

Deste modo, faz-se mister interpretar o art. 150, VI, d, da Constituição Federal como meio de garantir a imunidade tributária ao livro em sua ampla acepção, abrangendo todas as mídias existentes de difusão do pensamento, assim como seus insumos; não somente o livro impresso e a sua matériaprima por excelência, o papel.

De outra forma, negar uma interpretação extensiva à imunidade do livro resultaria em não dar à Constituição sua máxima efetividade, pois ao proteger a liberdade de expressão em seu sentido substancial (de forma precária, diga-se de passagem, por não a preservar em todas as suas dimensões) e não instrumental, a deixa vulnerável ao exercício autoritário do poder, obstaculizando a plena realização da democracia. Ademais, incorreria o hermeneuta no desrespeito a outros valores fundamentais da Constituição, como a produção, promoção e difusão dos bens culturais e a democratização 
de acesso aos bens de cultura (ambos encartados no art. $215, \S 3^{\circ}$, II e IV, respectivamente); a promoção do desenvolvimento científico (art. 218); a materialização de um ambiente ecologicamente equilibrado (art. 225); e o acesso à educação (art. $6^{\circ}$ ).

Ante o exposto, constata-se que um Estado que se pretende Democrático de Direito exige uma ampla e completa proteção da liberdade de expressão em seu sentido pleno (ambas as dimensões), especialmente contra o poder tributário, porquanto este, quando não constitui uma forma de censura (ainda que indireta), representa um entrave ao exercício da democracia, à materialização da Constituição, à garantia da dignidade da pessoa humana e a consecução dos objetivos fundamentais da República.

\section{REFERÊNCIAS}

BRANCO, Paulo Gustavo Gonet; COELHO, Inocêncio Mártires; MENDES, Gilmar Ferreira. Curso de Direito Constitucional. 4a Ed. São Paulo:

Saraiva, 2009.

CANOTILHO, José Joaquim Gomes. Direito Constitucional e Teoria da Constituição. $7^{\text {a }}$ Ed. Coimbra: Livraria Almedina, 2003.

CARRAZZA, Roque Antonio. Curso de Direito Tributário. $25^{\text {a }}$ Ed. São Paulo: Malheiros, 2009.

CARVAlHO, Paulo de Barros. Curso de Direito Tributário. $22^{\mathrm{a}}$ Ed. São Paulo: Saraiva, 2010.

MACHADO, Hugo de Brito. Imunidades. In: MARTINS, Ives Gandra (coordenador). Imunidades. São Paulo: Editora Revista dos Tribunais: Centro de Extensão Universitária, 1998.

. Curso de Direito Tributário. 24a Ed. São Paulo: Malheiros, 2004.

NUNES JÚNIOR, Vidal Serrano. A Proteção Constitucional da Informação e o Direito à Crítica Jornalística. São Paulo: FTD, 1997.

RUFIA, Paolo Biscaretti de. Introduzione al diritto constituzionale comparato. $2^{\text {a }}$ Ed., Milano: Giuffrè, 1970. 
SILVA, José Afonso da. Ordenação Constitucional da Cultura.

São Paulo: Malheiros Editores, 2001.

. Curso de Direito Constitucional Positivo. $25^{\text {a }}$ Ed., São Paulo:

Malheiros Editores, 2005.

. Aplicabilidade das normas constitucionais. $7^{\text {a }}$ Ed., São Paulo:

Malheiros Editores, 2008b.

. Curso de Direito Constitucional Positivo. $30^{\mathrm{a}}$ Ed., São Paulo:

Malheiros Editores, 2008a.

SOUZA, Nuno e. Liberdade de Imprensa. Dissertação para exame de Curso de Pós-Graduação em Ciências Jurídico-Política da Faculdade de Direito de Coimbra, 1984.

TAVARES, André Ramos. Curso de Direito Constitucional. $5^{\text {a }}$ Ed. rev. e atual. São Paulo: Saraiva, 2007.

Recebido em: 15/02/2012 Aprovado para publicação: 11/04/2013

Como citar: LOPES, Isabela Moraes de Almeida; FILHO, Tadeu José Migoto. A Interpretação da Imunidade do art. 150, VI, d, da Constituição Federal em Conformidade com o Estado Democrático de Direito. Revista do Direito Público, Londrina, v.8, n.1, p.137-154, jan./abr.2013. DOI: 10.5433/1980-511X.2013v8n1p137. 